\title{
Anonychia with flexural pigmentation
}

INSERM

\section{Source}

INSERM. (1999). Orphanet: an online rare disease and orphan drug data base. Anonychia with flexural pigmentation. ORPHA:69125

Anonychia with flexural pigmentation is characterised by anonychia and skin abnormalities (hyper- and hypopigmentation in axillae and groins, dry palmar and plantar skin leading to sore and cracked soles). It has been described in a mother and her two children. The mode of transmission is autosomal dominant. 